\title{
Validity of Guided Inquiry Based Learning Tools Guided in Practicing Performance Skills
}

\author{
Kartika Drajad Prehastuti ${ }^{*}$, Supramono, Bambang Suharto
}

Masters Program of Natural Sciences Teaching, Lambung Mangkurat University, Banjarmasin, Indonesia

\author{
DOI: $10.36348 /$ jaep.2020.v04i03.005 \\ | Received: 07.03.2020 | Accepted: 14.03.2020 | Published: 21.03.2020 \\ *Corresponding author: Kartika Drajad Prehastuti
}

\section{Abstract}

Learning Natural Sciences in Vocational Schools requires an assessment that emphasizes the scientific process and learning outcomes related to natural events around. But in reality until now science learning is still centered on the teacher and during learning more use textbooks and assessment only in the form of a written test at the end of the lesson. This results in low student performance skills and learning outcomes. One of the supporters who can practice the performance skills and student learning outcomes is a learning tool based on guided inquiry. This study aims to determine the appropriateness of guided inquiry-based science learning tools to practice vocational student performance skills. The device development is based on the Dick \& Carey development research model so as to produce learning devices that are tested to the field test stage. The validity of the device is validated by experts, then in this observation also observes the activities of teachers and students, student responses, the influence of the use of learning tools, and student performance skills. The results showed that; (1) guided inquiry-based science learning tools are declared valid by experts, (2) teacher and student activities are categorized as good, (3) student responses show positive responses, (4) and there is an increase in student learning outcomes by $78.60 \%$ and Student performance skills improve with each meeting and have good criteria. Based on the results of a descriptive analysis of the learning tools developed it is said to be feasible and able to train performance skills.

Keywords: learning tools, guided inquiry, performance skills.

Copyright @ 2020: This is an open-access article distributed under the terms of the Creative Commons Attribution license which permits unrestricted use, distribution, and reproduction in any medium for non-commercial use (NonCommercial, or CC-BY-NC) provided the original author and sources are credited.

\section{INTRODUCTION}

The 2006 Education Unit Level Curriculum (KTSP) in Natural Sciences (IPA) for Vocational Schools requires an assessment that emphasizes the scientific process and learning outcomes related to natural events around. This is a challenge for science teachers to be able to choose and use models that can bring students in a scientific process to form scientific attitudes, bringing students closer to their surroundings. However, based on the results of direct interviews with science subject teachers, information has been obtained so far the class learning has only centered on the teacher. Teaching materials used in class are standard instructional materials published by publishers but often do not meet student needs. Even this teaching material is not equipped with the availability of clear assessment rubrics, making it difficult for teachers when they want to use it to see student achievement. Class assessments that have been conducted so far only revolve around written and oral assessments, which emphasize more on the cognitive aspects, meaning that the assessment is done at the end of learning. The results of interviews with science teachers are supported by data on the value of students 'work skills in the competency test, the results show that the average value of students' work skills does not meet the expected criteria. Not yet achieved the expected performance skills because the teacher has not directed students with models that support performance skills.

One of the learning models that leads to the 2006 SBC demands is the guided inquiry learning model. Guided inquiry learning is a learning strategy that emphasizes the development of cognitive, affective, and psychomotor aspects in a balanced manner so that learning with this strategy is considered more meaningful[1]. In addition to the use of models, learning tools are also factors that play a role in determining the success of learning in schools. If a learning device is designed correctly it will bring the impact of convenience for students to be able to understand the contents of the material being studied. Conversely, if a learning device is incomplete and less systematic it will also have the effect of less effective 
learning. Therefore it is necessary to develop a learning device that is truly suited to the conditions of the characteristics and needs of students to improve their understanding and thinking ability. The learning device is one of the prerequisites for the implementation of the teaching and learning process properly and correctly [2].

The ideal learning device is a learning device that is flexible, contextual, and easy to apply. Characteristics of a good science learning device if used will be able to achieve optimal results, because in its application always prioritizes scientific processes, products, and attitudes as the nature of science itself. This is a form of technological improvement, especially in the field of education and teaching in schools.

One of the class assessments is performance evaluation (performance test). Performance tests can be used to help students get used to showing their performance in understanding and solving problems. Performance appraisal has the advantage of being able to reveal the potential of students in solving problems, reasoning, and communication in written and oral form. One feature of performance appraisal is the assessment of the learning process. Performance appraisal is based on observers 'observations of students' activities as they occur. In this study the performance or performance skills to be observed are as follows; (1) formulating problems, (2) formulating hypotheses/predictions, (3) writing observational procedures, (4) making observations, (5) making conclusions.

Nurdin in his research gained very good student argumentation skills, which meant that the product developed was appropriate in measuring aspects of observed skills and had standard language and rubrics that were suitable for use [3]. The results of other studies in the application of the guided inquiry model to the scientific thinking process skills through the guided inquiry model in its findings the researcher explained the results of the students' complete process skills classically [4]. In addition, in the study of the application of problem posing to improve the performance skills of 10th grade students of SMAN 4 Palangkaraya on ecosystem material, the student's performance has increased [5]. In the final evaluation it has really improved, students' skills are in the excellent and good category.

The 2006 SBC demands on science subjects for SMK/MAK are developing analytical, inductive, and deductive thinking skills to solve problems related to natural events around, and requires students to play an active role in the learning process (student centered). During this time learning is still using conventional methods, which tend to be monotonous and teachercentered. In addition, the assessment and learning tools used so far have not met the expected standards. This situation will have an impact on suboptimal learning outcomes.

\section{RESEARCH METHODS}

The Learning Device Development Activity in this study adopted the Dick and Carey model [6] which has been adjusted according to the needs in development. It all starts from identifying the research objectives and then continuing with the process of learning analysis and identifying the initial characteristics of students simultaneously. After obtaining new results can then be continued by making learning tools systematically and evaluated in the final stage. Evaluation is used to see the finished device can be accepted as a product that is ready or not and still needs to be revised. Learning tools developed include syllabus, lesson plans, teaching materials, and research sheets.

There are four types of formative evaluations that can be applied to develop this learning tool, namely (1) expert review; (2) individual trials (one-to-one evaluation); (3) small group evaluation; and (4) field evaluations. Specifically for this study only discussed about the validity of the device. The expert review stage is important to see the impact of learning tools. A valid learning tool can make learning in the classroom practical and effective. The results of the expert review will bear fruit and continue the revision of the compiler. The revised product development is carried out on each component of the learning device, namely: (a) the specific objectives of learning, (b) the contents of learning materials, (c) illustrations / drawings, and (d) formative evaluation. The results of the revision of this first stage can later be continued to the next stage. Desired data in the Learning Device Development activities in the form of suggestions, responses and improvements.

\section{RESEARCH RESULTS AND DISCUSSION \\ Learning Tools Validation Results}

Validated learning tools include syllabus, lesson plans, teaching materials, worksheets and assessment sheets on the Basic Competence (KD) identifying the type of waste. The focus of product validation development is on content validation (content) conducted by 3 validators. Three validators consist of 3 experts. One expert is a science education instructional design expert. Two other experts are chemistry education evaluation experts.

\section{Syllabus Validation Results}

A summary of the results of the syllabus validation by three experts is presented in the following Table 1. 
Table-1: Syllabus Validation Results

\begin{tabular}{|l|l|c|c|c|c|c|}
\hline \multirow{2}{*}{ No } & \multicolumn{1}{|c|}{ Validated Indicators/Aspects } & \multicolumn{1}{|c|}{ Validator } & Modus & Category \\
\cline { 3 - 5 } & & P.1 & P.2 & P.3 & & \\
\hline 1 & $\begin{array}{l}\text { Systematic sequence of preparation of syllabus (including SK, BC, } \\
\text { main material, learning, assessment, time allocation, as well as } \\
\text { media, tools and materials) }\end{array}$ & 4 & 3 & 4 & 4 & Very Valid \\
\hline 2 & Compliance SK with KD & & & \\
\hline 3 & Coverage of subject matter supports the achievement of KD & 3 & 4 & 4 & 4 & Very Valid \\
\hline 4 & $\begin{array}{l}\text { Learning is designed and developed based on SK, KD, and student } \\
\text { potential }\end{array}$ & 4 & 4 & 4 & 4 & Very Valid \\
\hline 5 & $\begin{array}{l}\text { Inclusion of observing, questioning, collecting data } \\
\text { (experiment/exploration), associating, and communicating to the } \\
\text { learning section (learning activities) }\end{array}$ & 3 & 2 & 3 & 3 & Valid \\
\hline 6 & $\begin{array}{l}\text { The determination of assessment is adjusted to SK, KD, subject } \\
\text { matter, and learning }\end{array}$ & 4 & 3 & 4 & 4 & Very Valid \\
\hline 7 & $\begin{array}{l}\text { Determination of media, tools, and materials adapted to SK, BC, } \\
\text { subject matter, learning, and assessment }\end{array}$ & 4 & 3 & 4 & 4 & Very Valid \\
\hline 8 & Use of language in accordance with EYD & 3 & 2 & 3 & 3 & Valid \\
\hline 9 & Simplicity of sentence structure & 3 & 4 & 4 & 4 & Very Valid \\
\hline 10 & $\begin{array}{l}\text { Suitability of the time allocation used with learning (learning } \\
\text { activities) }\end{array}$ & 4 & 3 & 4 & 4 & Very Valid \\
\hline
\end{tabular}

\section{RPP Validation Results}

A summary of the results of the RPP validation by three experts is presented in Table 2 below.

Table-2: RPP Validation Results

\begin{tabular}{|c|c|c|c|c|c|c|}
\hline \multirow[t]{2}{*}{ No } & \multirow[t]{2}{*}{ Validated Indicators/Aspects } & \multicolumn{3}{|c|}{ Validator } & \multirow[t]{2}{*}{ Modus } & \multirow[t]{2}{*}{ Category } \\
\hline & & P.1 & P.2 & P.3 & & \\
\hline 1 & $\begin{array}{l}\text { Complete RPP components (including identity, subjects, SK, KD, } \\
\text { learning objectives, indicators of competency achievement, teaching } \\
\text { materials / materials, time allocation, methods, learning activities, } \\
\text { assessment of learning outcomes and learning resources) }\end{array}$ & 4 & 4 & 4 & 4 & Very Valid \\
\hline 2 & $\begin{array}{l}\text { Inclusion of student preparation activities for learning, motivating, } \\
\text { apperception, information on learning objectives, and material } \\
\text { information }\end{array}$ & 3 & 3 & 2 & 3 & Valid \\
\hline 3 & $\begin{array}{l}\text { Clarity and logical formulation of learning objectives and } \\
\text { encouragement for critical thinking skills }\end{array}$ & 3 & 2 & 3 & 3 & Valid \\
\hline 4 & $\begin{array}{l}\text { Completeness of the formulation of learning objectives, explicit } \\
\text { aspects of } \mathrm{ABCD} \text { in formulating learning objectives }(\mathrm{A}=\text { audience, } \\
\mathrm{B}=\text { behavior, } \mathrm{C}=\text { condition, and } \mathrm{D}=\text { degree })\end{array}$ & 3 & 2 & 3 & 3 & Valid \\
\hline 5 & $\begin{array}{l}\text { There is integration of critical thinking skills in RPP (value } \\
\text { orientations that are internalized to practice critical thinking skills } \\
\text { appear explicitly in the formulation of learning objectives) }\end{array}$ & 3 & 2 & 3 & 3 & Valid \\
\hline 6 & Inclusion of preliminary (initial), core, and closing (final) activities & 3 & 4 & 4 & 4 & Very Valid \\
\hline 7 & $\begin{array}{l}\text { The suitability of the steps (learning experience) with the learning } \\
\text { objectives and time allocation }\end{array}$ & 4 & 3 & 4 & 4 & Very Valid \\
\hline 8 & $\begin{array}{l}\text { Inclusion of observing, questioning, collecting data (experiment / } \\
\text { exploration), associating, and communicating }\end{array}$ & 4 & 3 & 4 & 4 & Very Valid \\
\hline 9 & $\begin{array}{l}\text { Learning steps enable the growth of various life skills (critical } \\
\text { thinking skills, personal, social, academic, and vocational) }\end{array}$ & 4 & 3 & 4 & 4 & Very Valid \\
\hline 10 & $\begin{array}{l}\text { Learning activities and steps emphasize student learning experiences } \\
\text { rather than emphasizing teacher teaching experiences }\end{array}$ & 4 & 3 & 4 & 4 & Very Valid \\
\hline 11 & $\begin{array}{l}\text { Utilization of learning resources available in the immediate } \\
\text { environment of students }\end{array}$ & 3 & 2 & 3 & 3 & Valid \\
\hline 12 & $\begin{array}{l}\text { Potential use of learning media in making it easier for students to } \\
\text { learn }\end{array}$ & 3 & 2 & 3 & 3 & Valid \\
\hline 13 & $\begin{array}{l}\text { Utilizing potential learning models in activating and making } \\
\text { students creative }\end{array}$ & 4 & 3 & 4 & 4 & Very Valid \\
\hline 14 & Lists the tools and materials used during the learning & 3 & 2 & 3 & 3 & Valid \\
\hline 15 & $\begin{array}{l}\text { Include assessment instruments for the purpose of evaluating and } \\
\text { evaluating learning outcomes, both in the form of tests and non-tests }\end{array}$ & 4 & 4 & 3 & 4 & Very Valid \\
\hline 16 & Include reference sources in the lesson plan & 4 & 3 & 3 & 3 & Valid \\
\hline
\end{tabular}


Student Worksheet Validation Results (LKS)

A summary of the results of LKS validation by three experts is presented in the following Table 3.

Table-3: LKS Validation Results

\begin{tabular}{|l|l|c|c|c|c|c|}
\hline No & \multicolumn{1}{|c|}{ Validated Indicators/Aspects } & \multicolumn{2}{|c|}{ Malidator } & \multirow{2}{*}{ Mategory } \\
\cline { 3 - 5 } & & P.1 & P.2 & P.3 & & \\
\hline 1 & LKS emphasizes aspects of the process of finding concepts & 4 & 4 & 4 & 4 & Very Valid \\
\hline 2 & The accuracy of the cases presented & 4 & 3 & 4 & 4 & Very Valid \\
\hline 3 & $\begin{array}{l}\text { Systematic sequence (problem orientation, problem } \\
\text { formulation, predictions, tools and materials, procedures, } \\
\text { observations/data collection, data analysis, and conclusions) }\end{array}$ & 4 & 3 & 4 & 4 & Very Valid \\
\hline 4 & $\begin{array}{l}\text { The use of images that are interesting and support the } \\
\text { material/case presented }\end{array}$ & 3 & 3 & 2 & 3 & Valid \\
\hline 5 & Use of language in accordance with EYD & 4 & 3 & 3 & 3 & Valid \\
\hline 6 & Simplicity of sentence structure & 3 & 4 & 4 & 4 & Very Valid \\
\hline 7 & Attractive LKS display & 4 & 3 & 3 & 3 & Valid \\
\hline 8 & Efficiency of worksheets in relation to time & 4 & 3 & 4 & 4 & Very Valid \\
\hline 9 & Efficiency of worksheets in relation to costs & 3 & 4 & 4 & 4 & Very Valid \\
\hline
\end{tabular}

\section{Results of Validation of Teaching Materials}

A summary of the results of the validation of the Teaching Materials by three experts is presented in the following Table 4.

Table-4: Teaching Material Validation Results

\begin{tabular}{|c|c|c|c|c|c|c|}
\hline \multirow[t]{2}{*}{ No } & \multirow[t]{2}{*}{ Validated Indicators/Aspects } & \multicolumn{3}{|c|}{ Validator } & \multirow[t]{2}{*}{ Modus } & \multirow[t]{2}{*}{ Category } \\
\hline & & $\mathbf{P . 1}$ & $\mathbf{P . 2}$ & $\mathbf{P . 3}$ & & \\
\hline 1 & $\begin{array}{l}\text { The material is relevant to the competencies that students must } \\
\text { master }\end{array}$ & 4 & 3 & 4 & 4 & Very Valid \\
\hline 2 & $\begin{array}{l}\text { Depth of description in accordance with the level of student } \\
\text { development }\end{array}$ & 4 & 3 & 4 & 4 & Very Valid \\
\hline 3 & The material presented is in accordance with scientific truth & 4 & 3 & 3 & 3 & Valid \\
\hline 4 & $\begin{array}{l}\text { The material presented in accordance with the latest } \\
\text { developments }\end{array}$ & 3 & 3 & 2 & 3 & Valid \\
\hline 5 & The material presented in accordance with daily life & 4 & 4 & 4 & 4 & Very Valid \\
\hline 6 & Encourage students' curiosity & 3 & 2 & 3 & 3 & Valid \\
\hline 7 & Encourage student interaction with learning resources & 3 & 2 & 3 & 3 & Valid \\
\hline 8 & Encourage students to build their own knowledge & 3 & 2 & 3 & 3 & Valid \\
\hline 9 & Systematic order of matter & 3 & 3 & 3 & 3 & Valid \\
\hline 10 & $\begin{array}{l}\text { Sentence structure according to the level of understanding of } \\
\text { students }\end{array}$ & 4 & 4 & 3 & 4 & Very Valid \\
\hline 11 & $\begin{array}{l}\text { Making paragraphs/paragraphs according to the level of } \\
\text { student understanding }\end{array}$ & 3 & 2 & 3 & 3 & Valid \\
\hline 12 & $\begin{array}{l}\text { Use of pictures that support the explanation/description of the } \\
\text { material }\end{array}$ & 3 & 3 & 2 & 3 & Valid \\
\hline 13 & $\begin{array}{l}\text { Presentation of the picture is equipped with a description of the } \\
\text { picture }\end{array}$ & 4 & 3 & 4 & 4 & Very Valid \\
\hline 14 & Spelling accuracy & 3 & 3 & 2 & 3 & Valid \\
\hline 15 & Accuracy in terms of use & 4 & 3 & 3 & 3 & Valid \\
\hline 16 & Accuracy in structuring sentences & 4 & 3 & 3 & 3 & Valid \\
\hline
\end{tabular}

\section{Learning Test Validation Results}

A summary of the results of the validation of the Learning Outcomes Test by three experts is presented in the following Table 4.

Table-5: Validation Results Learning Outcomes Test

\begin{tabular}{|c|l|c|c|c|c|c|}
\hline \multirow{2}{*}{ No } & \multicolumn{1}{|c|}{ Validated Indicators/Aspects } & \multicolumn{2}{|c|}{ Validator } & \multirow{2}{*}{ Modus } & \multirow{2}{*}{ Category } \\
\cline { 3 - 5 } & & P.1 & P.2 & P.3 & & \\
& & & \\
\hline 2 & Instructions in answering questions are given coherently and clearly & 4 & 4 & 4 & 4 & Very Valid \\
\hline 3 & Each item is in accordance with the learning objectives & 3 & 4 & 3 & 3 & Valid \\
\hline 4 & Use of language in accordance with EYD & 4 & 4 & 3 & 4 & Very Valid \\
\hline
\end{tabular}




\section{Discussion of the Validity of Learning Devices}

The validity of the learning kit includes syllabus, lesson plans, worksheets and teaching material on the topic of waste. The results of the assessment by the validators namely the device as a whole are declared valid. Based on the average criteria of the validator assessment results in table 4 states that the syllabus is classified as very valid. This is because most of the indicators for evaluating syllabus validity have received optimal scores from validators. Achievement scores that are classified as valid for each indicator are obtained because in the syllabus development process the researcher has compiled the syllabus according to the instructional design rules. Syllabus development refers to the principle of device development according to the provisions of the National Education Standards Agency (BSNP) so that a guided inquiry-based device is produced that is consistent with the 2006 curriculum.

The impact of a valid learning tool is that learning can be carried out practically and effectively. Practicality of learning is evident from the results of the assessment of student and teacher activities that are classified as very good. The effectiveness of learning is evident from the cognitive learning outcomes of products and processes that are classified as good. On the learning device, the product cognitive learning outcomes are assessed from the product cognitive tests at the end of the learning. Whereas the results of the performance skills are assessed based on the student performance appraisal scores using LKS.

The results of cognitive assessment of products, performance skills, student and teacher activities as well as student motivation are good because the devices used have been arranged according to the characteristics of the guided inquiry model. The guided inquiry model is effective learning in building students' abilities [7]. Overall student performance and student activity in learning are influenced by the guided inquiry model [8].

Through learning models based on guided inquiry models with scientific methods the learning atmosphere in the classroom becomes more studentcentered so that it encourages students to be active. This is because the learning flow in the RPP motivates students to work actively solving problems. When students are active in learning activities, knowledge will be absorbed more. Referring to the guided inquiry model with a scientific approach to learning activities carried out by students in groups so as to make students active even for students who were previously classified as passive. Group activities in conducting activities at worksheets strongly support student learning environments.

\section{CONCLUSION}

The results of the validator's assessment of the learning tools include; syllabus, lesson plans, student worksheets, and teaching material. Before it was revised, it showed that there were several indicators which were declared less valid, namely systematic writing on the syllabus, inclusion of $5 \mathrm{M}$ activities in learning activities and suitability of time allocation. In addition, other indicators are declared to be quite valid with minor revisions. The revisions made include systematic improvements and grammar improvements in accordance with the general guidelines for Indonesian spelling. After the revision, the science learning tool developed was declared to be very valid or could be used without revision.

The science learning tools developed are stated to be very valid, having the understanding of learning tools that are developed in accordance with the objectives to be achieved in this research and development, can measure student performance skills, and can motivate students. The validity of the science learning tool is also because the product developed has gone through a process of identifying learning objectives, conducting learning analyzes, and identifying student characteristics that are adapted to BSNP.

The science learning tool is declared to be very valid, an indicator that the product developed has been able to become a medium for training the XI grade students' performance skills on the topic of waste. The learning tool in which LKS is able to motivate students to practice performance skills is inseparable from the content contained in the teaching material itself, as in accordance with their life context so that it is easy for students to understand.

The validity of science learning tools is done by a validator. The results of the expert review have met the very valid category. Achievement of the category is very valid in the science learning tools because the products developed can practice performance skills, in accordance with students' cognitive development, which is to begin developing the ability to make hypothetical formulations and use abstract principles.

\section{REFERENCES}

1. Shoimin, A. (2014). 68 model pembelajaran inovatif dalam kurikulum 2013. Yogyakarta: ArRuzz Media.

2. Supramono. (2013). Peningkatan Keterampilan Kinerja (Performance ) Siswa Kelas X 1 SMAN 4 Palangka Raya pada Materi Ekosistem dengan Menggunakan Pendekatan Problem Posing. Jurnal Pendidikan dan Pembelajaran, 74-84.

3. Nurdin, S. (2017). Pengembangan Performance Assessment Berbasis Inkuiri Terbimbing Untuk Mengukur Keterampilan Argumentasi Siswa di kelas XI SMA Bandar Lampung tahun ajaran 2016/2017. Bandar Lampung: Pascasarjana Universitas Bandar Lampung. 
Kartika Drajad Prehastuti et al; J Adv Educ Philos, March 2020; 4(3): 105-110

4. Yunita, E. (2016). Pengembangan Perangkat Pembelajaran Menggunakan Model Inkuiri Terbimbing Topik Klasifikasi Makhluk Hidup di SMP. Jurnal Inovasi Pembelajaran, 1-11.

5. Supramono. (2013). Peningkatan Keterampilan Kinerja (Performance) Siswa Kelas X1 SMAN 4 Palangka Raya pada Materi Ekosistem dengan Menggunakan Pendekatan Problem Posing. Jurnal Pendidikan dan Pembelajaran, 74-84.

6. Dick, W., Carey, L., \& Carey, J. (2001). The Systematic Design of Instruction. Fifth Edition. New York: Longman.
7. Fang, S. C., Hsu, Y. S., Chang, H. Y., Chang, W. H., Wu, H. K., \& Chen, C. M. (2016). Investigating the effects of structured and guided inquiry on students' development of conceptual knowledge and inquiry abilities: a case study in Taiwan. International Journal of Science Education, 1-27.

8. Minner, D. D., Levy, A. J., \& Century, J. (2009). Inquiry-Based Instruction -What Is It and Does It Matter? Results from a Research Synthesis Year 1984 to 2002. Journal of Research in Science Teaching, 474-496. 